\title{
Pola Peresepan Antibiotika Pada Kasus Infeksi Saluran Pernafasan Akut (Ispa) Di Klinik "X" Di Kota Malang Pada Bulan Mei - Desember 2008
}

\author{
Ika Ratna Hidayati*, Hidajah Rachmawati
}

\begin{abstract}
Program Studi Ilmu Farmasi Fakultas Ilmu Kesehatan Universitas Muhammadiyah Malang korespondensi:*ika_ratna80@yahoo.com
\end{abstract}

\begin{abstract}
ABSTRAK
Infeksi pada saluran napas merupakan penyakit yang umum terjadi pada masyarakat. Infeksi saluran napas berdasarkan wilayah infeksinya terbagi menjadi infeksi saluran napas atas dan infeksi saluran napas bawah. Infeksi saluran napas atas meliputi rhinitis, sinusitis, faringitis, laryngitis, epiglotitis, tonsillitis, otitis. Sedangkan infeksi saluran napas bawah meliputi infeksi pada bronchus, alveoli seperti bronchitis, bronkhiolitis, pneumonia. Penelitian ini dimaksudkan untuk melihat gambaran pola peresepan antibiotik pada kasus infeksi saluran pernapasan akut (ISPA) di Klinik "X" di Kota Malang pada bulan Mei-Desember 2008. Pengambilan data dilakukan secara retrospektif pada periode Mei sampai Desember 2008 di sebuah klinik " $X$ ” di Kota Malang, Jawa Timur. Semua pasien dengan semua jenis umur dan yang tercatat di dalam rekam medik di ambil sebagai sampel. Analisa dilakukan dengan metode deskriptif non analitik. Hasil penelitian menunjukkan bahwa dari 166 kasus infeksi saluran pernapasan akut, 69,87\% diantaranya pasien wanita, sedangkan sisanya 30,12\% adalah lakilaki. Antimikroba yang paling banyak digunakan adalah sefadroxil sebanyak 51,20\%, dan diikuti berturut - turut antibiotika Ciprofloxacin sebanyak 22,89\%, Amoxicillin sebanyak 12,05\%, Cotrimoxazol sebanyak 6,02\%, Thiamphenicol sebanyak 4,82\%, Erythromycin sebanyak 2,4\%, dan paling rendah adalah antibiotika Chloramphenicol sebanyak 0,60\%. Secara umum pemilihan dan penggunaan antimikroba untuk terapi pada pasien infeksi saluran pernapasan akut di Klinik "X" di Kota Malang, propinsi Jawa Timur bulan Mei-Desember 2008 sudah sesuai dengan referensi standard pelayanan kefarmasian.
\end{abstract}

Kata kunci : antibiotika, infeksi saluran nafas, pola peresapan

\section{Pendahuluan}

Infeksi pada saluran napas merupakan penyakit yang umum terjadi pada masyarakat. Infeksi saluran napas berdasarkan wilayah infeksinya terbagi menjadi infeksi saluran napas atas dan infeksi saluran napas bawah. Infeksi saluran napas atas meliputi rhinitis, sinusitis, faringitis, laryngitis, epiglotitis, tonsillitis, otitis. Sedangkan infeksi saluran napas bawah meliputi infeksi pada bronchus, alveoli seperti bronchitis, bronkhiolitis, pneumonia. Infeksi saluran napas atas bila tidak diatasi dengan baik dapat berkembang menyebabkan infeksi saluran napas bawah. Infeksi saluran napas atas yang paling banyak terjadi serta perlunya penanganan dengan baik karena dampak komplikasinya yang membahayakan adalah otitis, sinusitis, dan faringitis. (Depkes RI, 2001).

Secara umum penyebab dari infeksi saluran napas adalah berbagai mikroorganisme, namun yang terbanyak akibat infeksi virus dan bakteri. Infeksi saluran nafas dapat terjadi sepanjang tahun, meskipun beberapa infeksi lebih mudah terjadi pada musim hujan. Faktor - faktor yang mempengaruhi penyebaran infeksi saluran nafas antara lain faktor lingkungan, perilaku masyarakat yang kurang baik terhadap kesehatan diri maupun publik, serta rendahnya gizi. Faktor lingkungan meliputi belum terpenuhinya sanitasi dasar seperti air bersih, jamban, pengelolaan sampah, limbah, pemukiman sehat hingga pencemaran air dan udara. (Depkes RI., 2001).

Reaksi peradangan menyebabkan peningkatan pembentukan mukus yang berperan menimbulkan gejala - gejala infeksi saluran napas yaitu hidung tersumbat, sputum berlebihan, dan radang hidung ( pilek ). Nyeri kepala, demam ringan, dan malase juga timbul akibat reaksi peradangan. ( Corwin., J.E., 2001)

Tingginya prevalensi infeksi saluran pernapasan atas (ISPA) serta dampak yang ditimbulkannya membawa akibat pada tingginya konsumsi obat bebas (seperti anti 
influenza, obat batuk, multivitamin) dan antibiotika. Dalam kenyataan antibiotika banyak diresepkan untuk mengatasi infeksi ini. Peresepan antibiotika yang berlebihan tersebut terdapat pada infeksi saluran napas khususnya infeksi saluran napas atas akut, meskipun sebagian besar penyebab dari penyakit ini adalah ekspektasi yang berlebihan para klinisi terhadap antibiotika terutama untuk mencegah infeksi sekunder yang disebabkan oleh bakteri, yang sebetulnya tidak bisa dicegah. Dampak dari semua ini adalah meningkatnya resistansi bakteri maupun peningkatan efek samping yang tidak diinginkan. (Depkes RI., 2001).

Pemahaman masyarakat akan pneumonia masih sangat minim. Umumnya konsep yang ada di masyarakat mengenai pengertian pneumonia berbeda dengan konsep yang ada di pemerintah. Batuk pilek biasa oleh masyarakat disamakan dengan pneumonia, sedangkan yang dinamakan pneumonia sendiri adalah apabila batuk pilek disertai dengan kesukaran bernafas atau peningkatan frekuensi bernafas. Pneumonia menyerang saluran pernafasan bagian bawah tepatnya mengenai jaringan paru-paru (alveoli), sedangkan batuk pilek biasa (common cold) merupakan infeksi saluran pernafasan atas yang menyerang saluran pernafasan bagian atas. Selain kebiasaan tersebut, pemicu lainnya adalah keadaan lingkungan yang tidak sehat, terutama ketika banyak polusi udara. Daya tahan tubuh juga menjadi perihal penting untuk diperhitungkan dalam menghindari ISPA. Karena apabila ketahanan tubuh kurang, maka bakteri maupun virus dapat dengan mudah menembus kesehatan anda.

Tabel 1. Mikroba Patogen Penyebab Infeksi Saluran Pernafasan Akut (Pharmacoterapy Handbook)

\begin{tabular}{|l|l|}
\hline \multicolumn{1}{|c|}{ Jenis Infeksi } & \multicolumn{1}{|c|}{ Mikroba Patogen } \\
\hline $\begin{array}{l}\text { Infeksi Saluran } \\
\text { Pernafasan Atas }\end{array}$ & $\begin{array}{l}\text { Streptococcus pneumonia, } \\
\text { Haemophilus influenza, Moxarella } \\
\text { catarrhalis, }\end{array}$ \\
Infeksi Saluran & $\begin{array}{l}\text { Sterptococcus pyogenes, } \\
\text { Pernafasan }\end{array}$ \\
Bawah & $\begin{array}{l}\text { Mycoplasmaramydia pneumonia, rhinovirus, } \\
\text { Chlameumonia, } \\
\text { coronavirus, influenza virus, } \\
\text { adenovirus, Legionella } \\
\end{array}$ \\
\hline
\end{tabular}

Penanganan pengobatan kasus infeksi saluran pernapasan akut merupakan kunci keberhasilan. Pemberian obat dengan dosis, cara dan waktu yang tepat sangat membantu proses percepatan penyembuhan. Klinik " $X$ " di Kota Malang, Propinsi Jawa Timur merupakan tempat pelayanan kesehatan dengan jumlah kunjungan pasien infeksi saluran pernapasan akut tertinggi. Penelitian ini dimaksudkan untuk melihat gambaran pola peresepan antibiotik pada kasus infeksi saluran pernapasan akut (ISPA) di Klinik "X" di Kota Malang pada bulan Mei - Desember 2008.

\section{Metodologi}

Pengambilan data dilakukan secara retrospektif pada periode Mei sampai Desember 2008 di sebuah klinik "X" di Kota Malang, Jawa Timur. Semua pasien dengan semua jenis umur dan yang tercatat di dalam rekam medik di ambil sebagai sampel. Diagnosis di tegakkan dengan melihat gejala - gejala yang biasanya muncul, misalnya : demam, batuk pilek, nyeri kepala, dan tidak dilakukan uji laboratorium. Data yang diambil meliputi identitas responden (nama, jenis kelamin, umur), anamnesis, diagnosis, penggunaan obat berdasarkan diagnosis, cara pemberian, dan bentuk sediaan.

Data pasien yang diperoleh kemudian diolah dan disajikan dalam bentuk Tabel, kemudian dianalisa secara deskriptif non analitik (Nawawi, 2003), sehingga didapat gambaran pola peresepan Antibiotika pada kasus Infeksi Saluran Pernapasan Akut di Klinik "X" pada bulan Mei - Desember 2008 di Kota Malang, Jawa Timur.

\section{Hasil dan Pembahasan}

Hasil penelitian menunjukkan bahwa selama periode Mei sampai Desember 2008, di klinik "X" Kota Malang, Jawa Timur terdapat 555 pasien dengan berbagai macam diagnosis penyakit. Diagnosa terbanyak adalah Infeksi saluran pernafasan akut dengan jumlah 166 pasien, 69,87\% diantaranya pasien wanita, sedangkan sisanya 30,12\% adalah laki-laki (Tabel 2).

Data yang tercatat berdasarkan umur menunjukkan bahwa penderita kelompok umur >3-30 tahun terdapat paling banyak yakni $89,16 \%$ dan diikuti berturut-turut kelompok umur $>30-80$ tahun sebayak $6,63 \%$, kelompok umur $0-3$ tahun sebanyak $4,22 \%$ kasus (Tabel 3). 
Tabel 2. Distribusi Frekuensi Penderita ISPA Berdasarkan Jenis Kelamin di Sebuah Klinik "X" di Kota Malang, pada bulan Mei - Desember 2008

\begin{tabular}{|l|c|c|}
\hline $\begin{array}{c}\text { Jenis } \\
\text { Kelamin }\end{array}$ & $\begin{array}{c}\text { Jumlah } \\
\text { Penderita } \\
\text { ISPA }\end{array}$ & $\begin{array}{c}\text { Prosentase } \\
(\boldsymbol{\%})\end{array}$ \\
\hline Laki - laki & 50 & 30,12 \\
Perempuan & 116 & 69,87 \\
Total & $\mathbf{1 6 6}$ & $\mathbf{1 0 0}$ \\
\hline
\end{tabular}

Tabel 3. Distribusi Frekwensi Penderita ISPA berdasarkan umur di Sebuah Klinik "X" di Kota Malang, pada bulan Mei - Desember 2008

\begin{tabular}{|c|c|c|}
\hline $\begin{array}{c}\text { Kelompok } \\
\text { Umur }\end{array}$ & Jumlah & $\begin{array}{c}\text { Prosentase } \\
(\mathbf{\%})\end{array}$ \\
\hline $0-3$ tahun & 7 & 4,22 \\
$>3-30$ tahun & 148 & 89,16 \\
$>30-80$ tahun & 11 & 6,63 \\
Total & $\mathbf{1 6 6}$ & $\mathbf{1 0 0}$ \\
\hline
\end{tabular}

Tabel 4. Distribusi Penggunaan Antibiotika di Klinik "X" di Kota Malang, pada bulan Mei - Desember 2008

\begin{tabular}{|c|c|c|}
\hline $\begin{array}{c}\text { Jenis } \\
\text { Antibiotika }\end{array}$ & $\begin{array}{c}\text { Jumlah } \\
\text { Pasien }\end{array}$ & $\begin{array}{c}\text { Prosentase } \\
(\mathbf{\%})\end{array}$ \\
\hline Amoxicillin & 20 & 12,05 \\
Cefadroxil & 85 & 51,20 \\
Ciprofloxacin & 38 & 22,89 \\
Cotrimoxazol & 10 & 6,02 \\
Chloramphenicol & 1 & 0,60 \\
Thiamphenicol & 8 & 4,82 \\
Erythromycin & 4 & 2,40 \\
Total & $\mathbf{1 6 6}$ & $\mathbf{1 0 0}$ \\
\hline
\end{tabular}

Tabel 5. Frekuensi Jumlah Penderita ISPA berdasarkan bulan di Klinik "X" di Kota Malang, pada bulan Mei Desember 2008

\begin{tabular}{|c|c|c|}
\hline Bulan & $\begin{array}{c}\text { Jumlah } \\
\text { Pasien }\end{array}$ & $\begin{array}{c}\text { Prosentase } \\
(\mathbf{\%})\end{array}$ \\
\hline Mei & 9 & 5,42 \\
Juni & 18 & 10,84 \\
Juli & 18 & 10,84 \\
Agustus & 16 & 9,64 \\
September & 7 & 4,22 \\
Oktober & 13 & 7,83 \\
November & 32 & 19,28 \\
Desember & 53 & 31,93 \\
Total & $\mathbf{1 6 6}$ & $\mathbf{1 0 0}$ \\
\hline
\end{tabular}

\section{Kesimpulan}

Sebagian besar pasien yang berkunjung di Klinik " $X$ " di Kota Malang,
Jawa Timur pada bulan Mei sampai Desember 2008 di diagnosis sebagai Infeksi Saluran Pernafasan Akut (ISPA). Terapi antibiotika terbanyak yang digunakan adalah antibiotika tunggal Cefadroxil sebanyak $51,20 \%$, di urutan ke dua antibiotika Ciprofloxacin sebanyak 22,89\%, kemudian antibiotika Amoxicillin sebanyak 12,05\%, Cotrimoxazol sebanyak $6,02 \%$, Thiamphenicol sebanyak $4,82 \%$, Erythromycin sebanyak 2,40\%, dan penggunaan paling sedikit adalah antibiotika Chloramphenicol sebanyak 0,60\%. Bulan kunjungan pasien terbesar yang didiagnosis sebagai Infeksi Saluran Pernapasan Akut (ISPA) adalah bulan Desember sebanyak $31,93 \%$, sedangkan kunjungan pasien terkecil yang didiagnosis sebagai Infeksi Saluran Pernapasan Akut (ISPA) adalah pada bulan September sebanyak 4,22\%.

\section{Daftar Pustaka}

Anonim, 2009, British National Formulary, 57 Ed., England, 297 - 298, 323 324.

Corwin., J.E., 2001, Buku Saku Patofisiologi, Edisi I, Penerbit Buku Kedokteran, $408-437$.

Depkes RI. 2001, Direktorat Bina Farmasi Komunitas Klinik Ditjen Bina Farmasi dan Alkes, Pharmaceutical Care Untuk Penyakit Infeksi Saluran Pernafasan, 1 - 4.

Nawaawi, H., 2003, Metode Penelitian Bidang Sosial. Cetakan ke-10. Gadjah Mada University Press. Yogyakarta. 149 - 150.

Wells, G.B., Dipiro,J., Schwinghammer, T., Hamilton, C., 2006, Pharmacotherapy Handbook, $6^{\text {th }} \mathrm{Ed}$., McGraw - Hill, 420 - 439.

Tan T.H., dan Rahardja, K., 2002, Obat-obat Penting, Edisi Kelima. PT Elex Media Komputindo Kelompok Gramedia, Jakarta, 68, 78 - 84, 